\title{
A revision of the genus Astatoreochromis (Teleostei, Cichlidae), East-Africa
}

\author{
Gaspard BANYANKIMBONA ${ }^{1,2,3,4}$ Emmanuel VREVEN ${ }^{1,2,5}$ and Jos SNOEKS 1,2,6,* \\ ${ }^{1}$ KU Leuven, Laboratory of Biodiversity and Evolutionary Genomics, Charles Deberiotstraat 32, \\ B-3000 Leuven, Belgium. E-mail: gaspard.banyankimbona@student.kuleuven.be \\ ${ }^{2}$ Royal Museum for Central Africa, Vertebrate section, Ichthyology, Leuvensesteenweg 13, B-3080 \\ Tervuren, Belgium. E-mails: emmanuel.vreven@africamuseum.be; jos.snoeks@africamuseum.be \\ ${ }^{3}$ University of Burundi, Department of Biology, P.O. Box 2700, Bujumbura, Burundi. \\ *Corresponding author: E-mail: jos.snoeks@africamuseum.be \\ ${ }^{4} \underline{\text { urn:1sid:zoobank.org:author:6B0D1714-87BA-46D0-A9B7-E097878BE91D }}$
${ }^{5} \underline{\text { urn:1sid:zoobank.org:author:852BA52E-FF0C-4E39-B4A7-0967DA0AF79A }}$
${ }^{6} \underline{\text { urn:1sid:zoobank.org:author:8841919C-2A14-4DEB-9CC4-69E3C8CA3295 }}$
}

Abstract. A taxonomic revision of the cichlid genus Astatoreochromis is presented. Eighteen meristic and 23 morphometric measurements were taken on 185 individuals, including type specimens. While fin counts separate populations from the Lake Victoria region (Astatoreochromis alluaudi) from those of the Rusizi and Malagarazi rivers in the Lake Tanganyika basin (A. vanderhorsti and A. straeleni respectively), clear differentiation was not detected between the latter two. Mann-Whitney U-tests on specimens of comparable size from the two Tanganyika populations revealed significant differences in specimens $<75 \mathrm{~mm}$ SL, mainly in pharyngeal jaw proportions, but also in some other measurements on the head and body. However, these differences were not detected in specimens $>75 \mathrm{~mm}$ SL and Astatoreochromis vanderhorsti is herein considered a junior synonym of $A$. straeleni. A redescription of the two valid species of Astatoreochromis, A. alluaudi and A.straeleni, is provided.

Key words. pharyngeal jaw proportions, haplochromine cichlid, synonym, Lake Victoria basin, Lake Tanganyika basin.

Banyankimbona G., Vreven E. \& Snoeks J. 2013. A revision of the genus Astatoreochromis (Teleostei, Cichlidae), East Africa. European Journal of Taxonomy 39: 1-21. http://dx.doi.org/10.5852/ejt.2013.39

\section{Introduction}

By far the highest diversity of cichlids occurs in the east and central African lakes Tanganyika, Victoria and Malawi, where they have speciated in great profusion (Stiassny \& Meyer 1999; Snoeks 2001). However, the taxonomic status of many species remains unresolved, and it has been suggested that the Cichlidae may actually pose more systematic problems than any other fish family (Snoeks 2004). 
Astatoreochromis Pellegrin, 1904 is a haplochromine genus (sensu Greenwood 1979) described by Pellegrin (1904) for A. alluaudi, based on four specimens collected by C. Alluaud in the Kavirondo Gulf of Lake Victoria (Kenya). According to Pellegrin (1904), the genus is distinguished from other haplochromine genera in having V-VI anal fin spines (vs. III in Haplochromis) and XVIII-XIX dorsal fin spines (vs. XII-XVI in Haplochromis). Boulenger (1907), however, placed Astatoreochromis in synonymy with Haplochromis, arguing that the higher number of dorsal and anal spines was due to a transformation of soft rays into spines and hence the increase in spine number related to a decrease in soft fin ray numbers and as such did not merit a different generic status. Greenwood (1959) redescribed the genus, adding more diagnostic features such as possession of a rounded caudal fin and the lack of marked sexual dimorphism. He recognized two subspecies: the nominal subspecies A. a. alluaudi from lakes Victoria and Kyoga, and the Victoria Nile; and A. a. occidentalis from lakes Edward, George, Nakavali and Kachira, and the Semliki River. Astatoreochromis a. occidentalis was distinguished from A. a. alluaudi in having a shorter, narrower and less massive lower pharyngeal jaw (LPJ) with fewer enlarged and molariform teeth. Relative LPJ size was expressed by Greenwood (1959) as a ratio of LPJ width to head length. However, Greenwood (1965a) later examined an aquarium-bred specimen from the Lake Victoria stock raised on a virtually mollusk-free diet at the AMNH (specimen not traceable) and concluded that, compared to the natural populations of A. a. alluaudi and A. a. occidentalis, the aquariumraised specimen, which appeared to be in good condition, had a much finer LPJ, with fewer enlarged, less flattened and less molariform teeth, and a reduction of the overall dimension of the neurocranial apophysis. Based on these observations Greenwood (1965a) no longer recognized subspecific division and considered $A$. alluaudi as a phenotypically variable species.

The original description of Haplochromis straeleni Poll, 1944 was based on a single specimen from the Lukuga River (Democratic Republic of Congo). Later, Poll (1974) reported eight additional specimens from the Rusizi River and redescribed the species. Based on these new specimens, which had 3-4 anal spines, rounded caudal fins and shared close similarities in colour pattern and the arrangement of anal ocelli with A. alluaudi, Poll (1974) reallocated H. straeleni to the genus Astatoreochromis.

Greenwood (1954) described a third nominal species as Haplochromis vanderhorsti, based on a holotype and 49 paratypes from the Malagarazi basin, and distinguished it from other fluviatile haplochromine species by its massive LPJ and dentition. Furthermore, $H$. vanderhorsti differed from $H$. straeleni in having a slightly deeper lachrymal, which covered the maxilla except for its posterior tip and with a mouth that is almost horizontal, rather than inclined as in A. straeleni.

The generic status of A. alluaudi, A. straeleni and H. vanderhorsti was reviewed by Greenwood (1979). As a result, he agreed with Poll's (1974) reallocation of H. straeleni to Astatoreochromis and also reallocated $H$. vanderhorsti to the same genus. Greenwood (1979) still recognized $A$. vanderhorsti and A. straeleni as distinct species but noted they closely resemble each other, differing only slightly in dorsal spine counts (XVI-XVII in A. vanderhorsti vs. XVII-XVIII in A. straeleni); in anal-fin spine counts (III in A. vanderhorsti vs. III-IV in A. straeleni); in LPJ size and shape (more massive vs. thinner), and the number of molariform teeth on the LPJ (more $v s$. less molariform teeth). Hoogerhoud (1986) agreed with this reallocation but stipulated that the close resemblance of $A$. straeleni and $A$. vanderhorst $i$ raises questions as to their validity as different taxa, a view later shared by De Vos et al. (2001a). To clarify this situation, a detailed morphometric study of the three nominal Astatoreochromis species was conducted, and the results are presented below.

\section{Material and methods}

\section{Acronyms}

$\mathrm{AMNH}=$ American Museum of Natural History, New York

$\mathrm{BMNH}=$ British Museum of Natural History (currently the Natural History Museum), London 


\author{
IRSNB $=$ Institut Royal des Sciences Naturelles de Belgique, Brussels \\ MNHN $=$ Musée National d'Histoire Naturelle, Paris \\ MRAC = Musée Royal de l'Afrique Centrale, Tervuren
}

\title{
Other abbreviations
}

$\begin{array}{ll}\text { HL } & =\text { Head Length } \\ \text { LPJ } & =\text { Lower Pharyngeal Jaw } \\ \text { MWU-test } & =\text { Mann-Whitney U-test } \\ \text { PC } & =\text { Principal Component } \\ \text { PCA } & =\text { Principal Component Analysis } \\ \text { SL } & =\text { Standard Length }\end{array}$

The specimens studied originate from various museum collections (MRAC, AMNH, BMNH, IRSNB and MNHN). Additional specimens recently collected (December 2008 to December 2012) by one of the authors (GB) from the Rusizi and the Malagarazi basins (Burundi) and deposited at the MRAC, were also included. In total, 185 specimens were examined (see catalogue numbers in the specimens examined sections below). This total includes 87 specimens labelled as A. alluaudi from lakes Victoria (12, including the lectotype and the three paralectotypes), Kyoga (2), Edward (5), George (3), Kayanza (4), Nakavali (13), and Nabugabo (4), the Semliki River (1), and the Upper and Middle Akagera basin (43) [referred to here as Lake Victoria basin specimens]; 57 specimens labelled as A. straeleni from the Rusizi drainage (including 12 dissected for gut content and gonad analysis) and the Lukuga River (2, including the holotype); and 41 specimens labelled as $A$. vanderhorsti including the holotype and the 19 paratypes from the Malagarazi [referred to as Lake Tanganyika basin specimens]. Counts and measurements follow Snoeks (2004). On each specimen 18 counts and 23 morphometric measurements (Fig. 1) were taken on the left side of the fish with dial calipers at $0.1 \mathrm{~mm}$ precision. For the two specimens from the Lukuga River, including the holotype of $A$. straeleni, the LPJ is missing and measurements could not be taken. Gut contents of 12 freshly collected specimens of $A$. straeleni from the Rusizi basin were also examined. Log-transformed measurements were analyzed with PCA based on the correlation matrix. The first component, having loadings of the same sign and of the same magnitude, was interpreted as a latent variable serving as a proxy for size (Bookstein et al. 1985). PCA on the meristics were performed on the correlation matrix of the raw data. Non-parametric Mann-Whitney U-tests, corrected with sequential Bonferroni correction (Rice 1989) for multiple comparisons, were performed on the meristics and the morphometric measurements. Additional qualitative observations such as the shape of oral and LPJ teeth, caudal fin shape, and shape of gill rakers were made following Barel et al. (1977). Data on colour patterns were taken from the literature, and from photographs and observations on live specimens (GB).

\section{Results}

\section{Meristics}

A first PCA on 22 meristics for all examined specimens revealed the presence of two major groups with minor overlap, one situated mainly on the negative part of the first axis and containing the Lake Victoria basin specimens, and the other, mainly situated on the positive part of the first axis, containing the Lake Tanganyika basin specimens (Fig. 2A). This first axis is mainly defined by the number of anal and dorsal spines and soft fin rays (see Table 1).

\section{Measurements}

A PCA performed on 23 log-transformed measurements did not result in a good separation between the Lake Victoria and the Lake Tanganyika basin populations (Fig. 2B). Interestingly, the highest loadings on the second axis were found for three measurements on the LPJ, i.e., dental area length, jaw width and 
dental area width (Table 2). A second PCA, excluding LPJ measurements, allowed for the inclusion of more specimens, but did not result in a separation of the Lake Victoria and Lake Tanganyika specimens either (results not shown). To further explore the structure within the two main groups, further PCAs were performed on the log-transformed measurements on each basin separately, first including and then
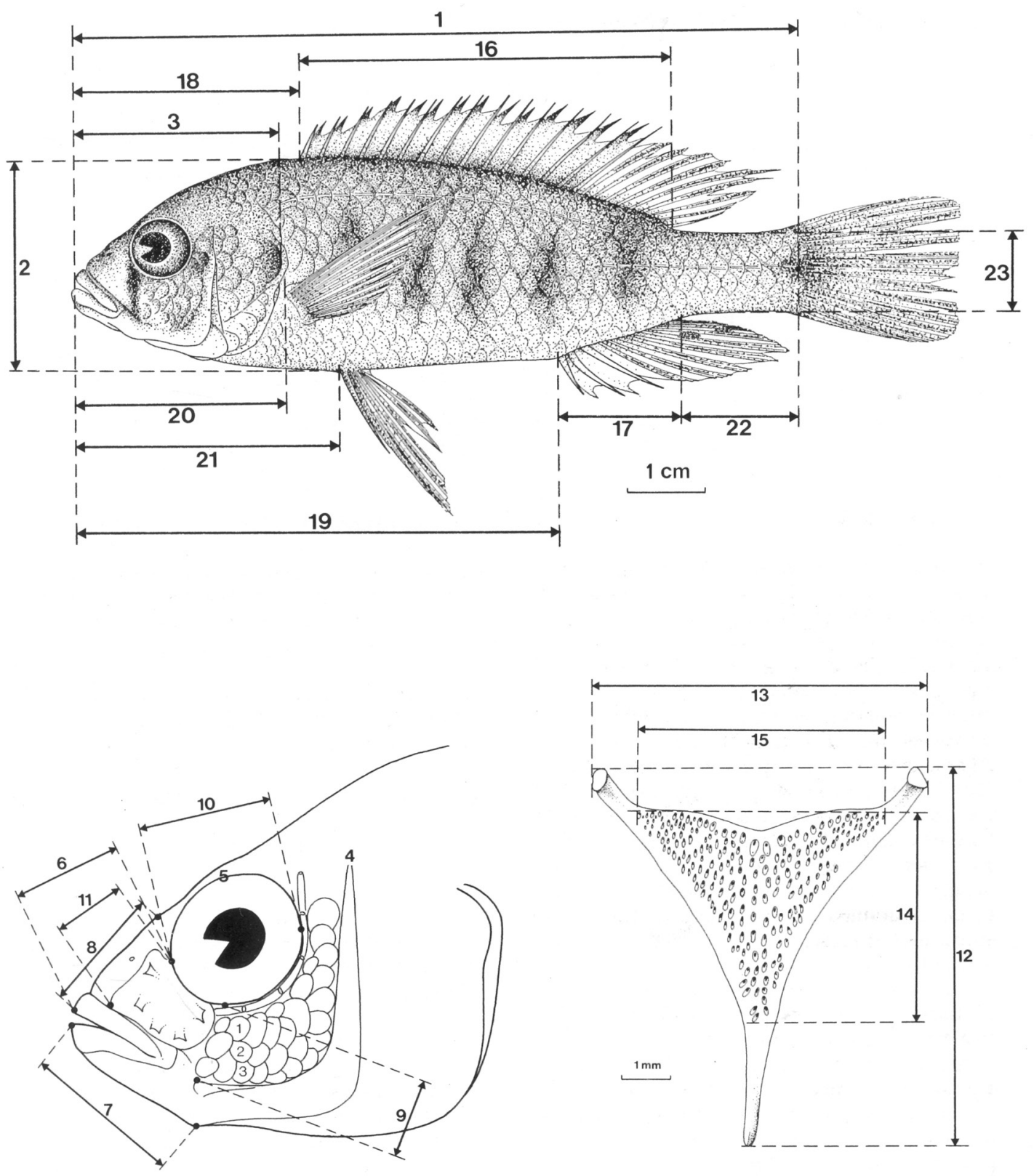

Fig. 1. Morphometric measurements of Astatoreochromis specimens (Snoeks 1994). Body measurements. 1. Standard length (SL). 2. Body depth. 16. Dorsal fin base length. 17. Anal fin base length. 18. Predorsal distance. 19. Preanal distance. 20. Prepectoral distance. 21. Prepelvic distance. 22. Caudal peduncle length. 23. Caudal peduncle depth. Head measurements. 3. Head Length. 4. Head width. 5. Interorbital width. 6. Snout length. 7. Lower jaw length. 8. Premaxillary pedicel length. 9. Cheek depth. 10. Eye diameter. 11. Lachrymal depth. Lower pharyngeal jaw (LPJ) measurements. 12. Lower pharyngeal length. 13. Lower pharyngeal width. 14. Dentigerous area length. 15. Dentigerous area width. 
BANYANKIMBONA G. et al., Revision of the cichlid genus Astatoreochromis

\begin{tabular}{|lccc|}
\hline Variable & PCI & PCII & PCIII \\
\hline Upper jaw teeth outer rows & 0.400115 & -0.255875 & 0.477645 \\
Lower jaw teeth outer rows & 0.317332 & -0.015766 & 0.430572 \\
Rows of teeth in the upper jaw & -0.365635 & 0.408450 & 0.425929 \\
Rows of teeth in the lower jaw & -0.261905 & 0.361547 & 0.506096 \\
Gill rakers on the ceratobranchial & 0.130150 & 0.686250 & -0.421600 \\
Gill rakers on the epibranchial & 0.296867 & 0.659946 & 0.050869 \\
Total gill rakers & 0.271459 & 0.870584 & -0.288812 \\
Dorsal fin spines & -0.859783 & 0.049764 & 0.173681 \\
Dorsal fin soft rays & 0.843430 & -0.019729 & 0.252684 \\
Dorsal fin total rays & -0.060116 & 0.046733 & 0.641217 \\
Anal fin spines & -0.932267 & 0.115080 & -0.058894 \\
Anal fin soft rays & 0.824954 & -0.004825 & 0.217621 \\
Anal fin total rays & -0.438535 & 0.209896 & 0.238043 \\
Pectoral fin rays & -0.285275 & -0.156201 & -0.149899 \\
Longitudinal line scales & 0.086237 & 0.391265 & 0.248040 \\
Upper lateral line scales & 0.368165 & 0.178543 & 0.200635 \\
Lower lateral line scales & -0.351788 & 0.152771 & 0.136138 \\
Upper transversal line scales & -0.110426 & -0.158029 & 0.043765 \\
Lower transversal line scales & -0.439168 & 0.169728 & 0.227318 \\
Scales between pectoral and pelvic fins & -0.393767 & -0.206011 & 0.057224 \\
Series of scales on the cheek & -0.338541 & 0.055883 & 0.116712 \\
Prp. Totl & 0.221947 & 0.115337 & 0.092417 \\
\hline
\end{tabular}

Table 1. Principal component loadings of the meristics on the first three axes of all Astatoreochromis specimens examined.

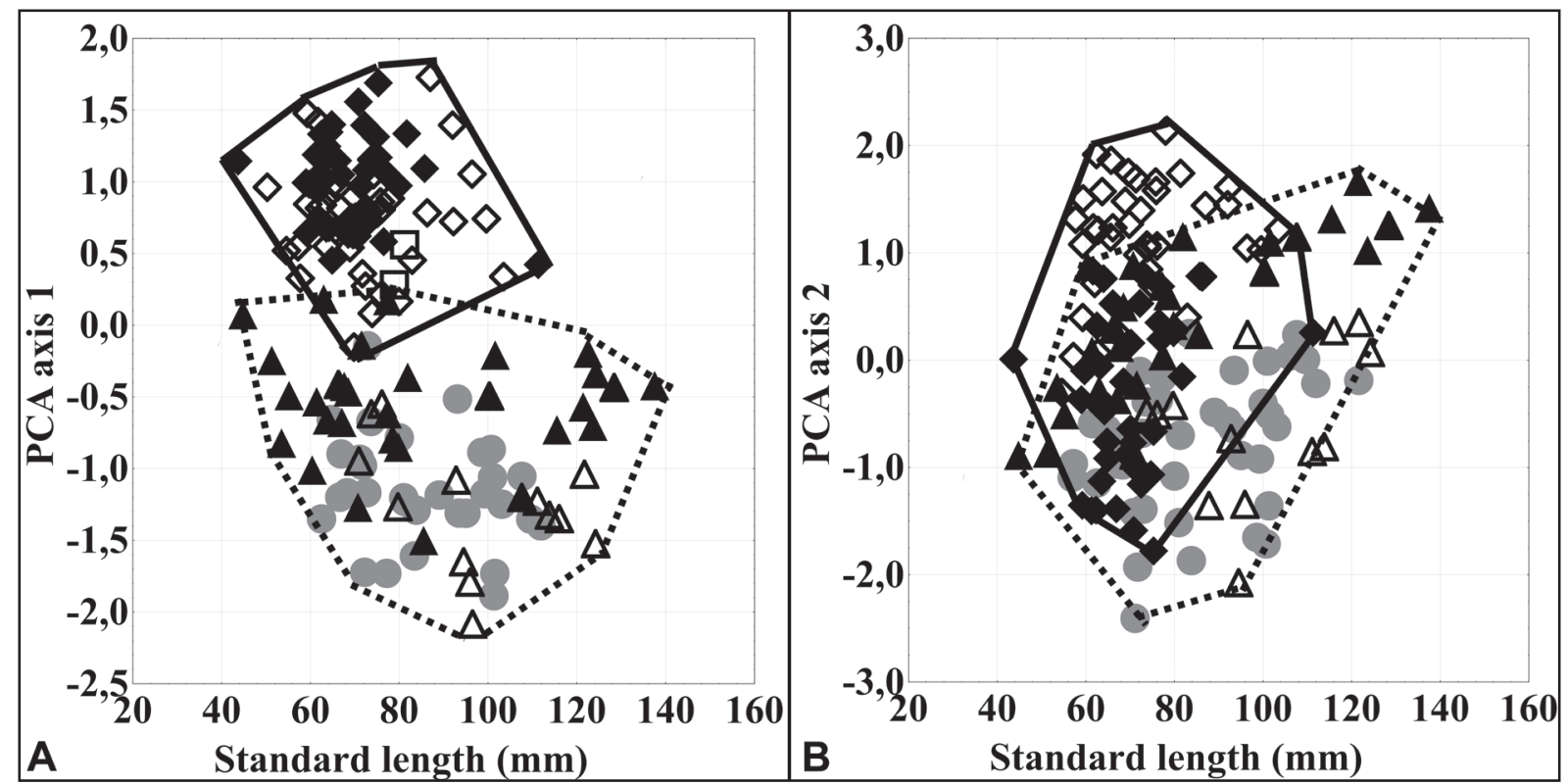

Fig. 2. Plots of PCA scores against standard length for all Astatoreochromis specimens examined. (A) scores on the first axis of a PCA on the meristics and (B) on the second axis of a PCA on the logtransformed morphometrics. Lakes Victoria and Kioga $(\Delta)$; Lakes Edward-George-Kayanza-NabugaboNakavali-Semliki ( $\Delta$ ); Akagera basin (•); Lukuga River ( $\square$ ), Malagarazi basin $(\diamond)$; Rusizi basin $(\diamond)$. Full line polygon for Lake Tanganyika basin, dashed line polygon for Lake Victoria basin specimens. 


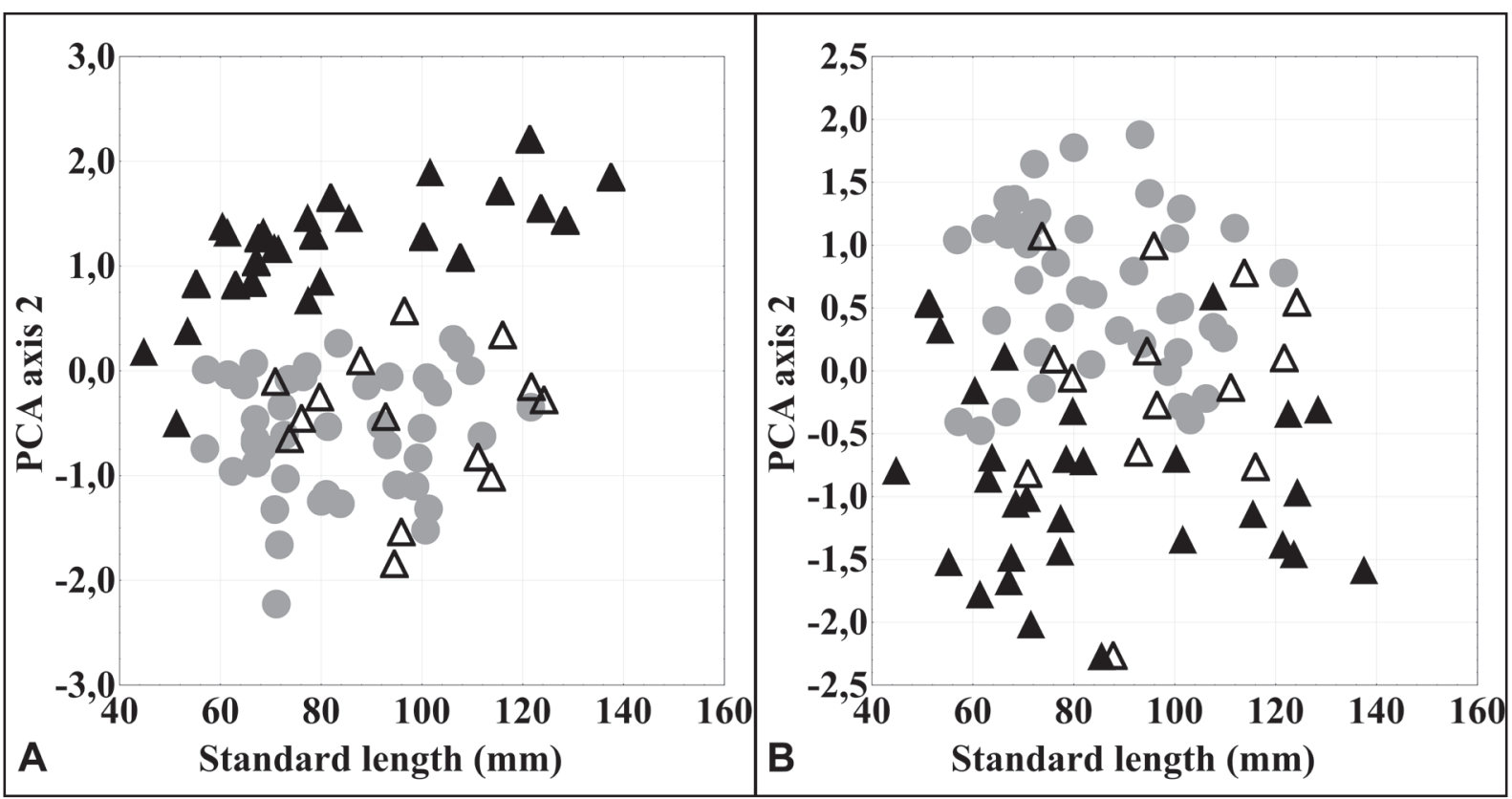

Fig. 3. Plots of the scores on the second axis of a PCA on the log-transformed measurements of Lake Victoria basin specimens against standard length, (A) including and (B) excluding lower pharyngeal bone measurements. Lakes Victoria and Kioga $(\Delta)$; Lakes Edward-George-Kayanza-NabugaboNakavali-Semliki ( $\boldsymbol{\Delta})$; Akagera basin (•).
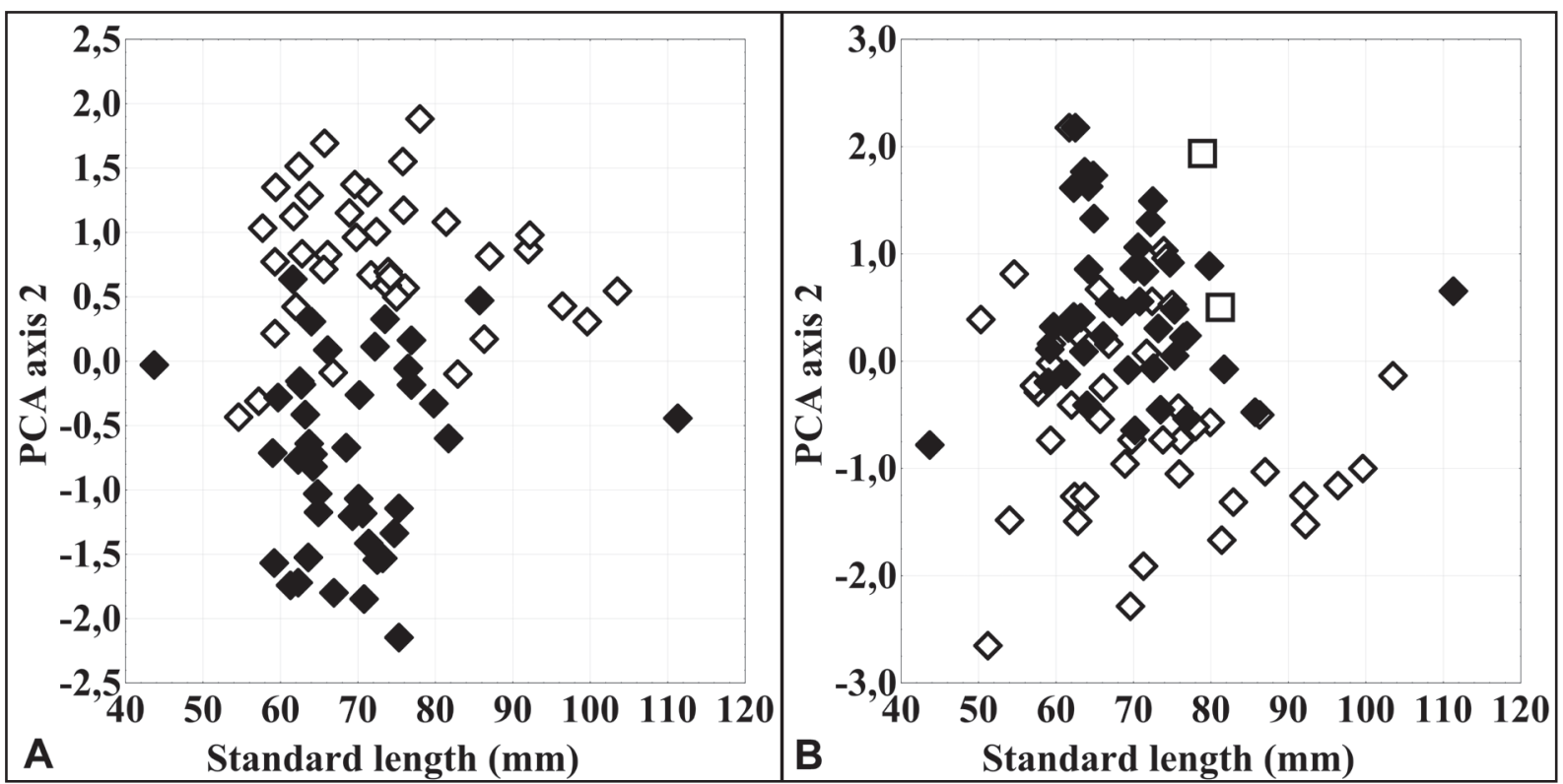

Fig. 4. Plots of the scores on the second axis of a PCA on the log-transformed measurements of Lake Tanganyika specimens against standard length, (A) including and (B) excluding lower pharyngeal bone measurements. Lukuga River $(\square)$, Malagarazi basin $(\diamond)$; Rusizi basin $(\diamond)$. 
excluding the LPJ measurements. For the first series of analyses, the most important loadings on the second axis again included LPJ measurements (Table 2), i.e., dental area length and jaw width for Lake Victoria, and jaw length and width, and dental area width and length for the Lake Tanganyika basin. The Lake Victoria specimens separated with minor overlap in two groups on the second axis in the first analysis (Fig. 3A), whereas, after removal of LPJ measurements, an overlap appeared on the second axis (Fig. 3B). The two groups correspond to (1) the specimens from lakes Victoria and Kyoga, the Upper and Middle Akagera and (2) those from lakes Edward, George, Kayanza, Nakavali, and Nabugabo, and the Semliki River. Within the Tanganyika basin, a separation was observed between the Rusizi and Malagarazi populations on the second axis in the first analysis (Fig. 4A). After removal of LPJ measurements, also in this case, the overlap became greater (Fig. 4B). The position of the two Lukuga specimens is equivocal; one of them, the holotype of $A$. straeleni, appears to be situated amongst the Malagarazi specimens rather than with the remaining Rusizi specimens.

\begin{tabular}{|c|c|c|c|c|c|c|c|c|c|c|}
\hline \multirow[t]{2}{*}{ Log-variable } & \multicolumn{2}{|c|}{$V$ and $T$} & \multicolumn{2}{|c|}{$\mathbf{V}$} & \multicolumn{2}{|c|}{$\begin{array}{l}V \text { minus } \\
\text { phar. jaw }\end{array}$} & \multicolumn{2}{|c|}{$\mathbf{T}$} & \multicolumn{2}{|c|}{$\begin{array}{l}\text { T minus } \\
\text { phar. jaw }\end{array}$} \\
\hline & PC1 & PC2 & PC1 & PC2 & PC1 & PC2 & PC1 & PC2 & PC1 & PC2 \\
\hline Lachrymal depth & -0.980 & 0.015 & -0.981 & 0.078 & -0.983 & -0.062 & -0.968 & -0.061 & -0.965 & 0.119 \\
\hline Snout length & -0.974 & 0.055 & -0.982 & 0.043 & -0.984 & 0.000 & -0.935 & 0.158 & -0.946 & 0.133 \\
\hline Lower jaw length & -0.979 & -0.007 & -0.978 & 0.038 & -0.980 & 0.019 & -0.967 & -0.052 & -0.968 & 0.102 \\
\hline Premaxillary pedicel length & -0.972 & -0.027 & -0.974 & -0.061 & -0.973 & 0.110 & -0.952 & -0.038 & -0.956 & 0.048 \\
\hline Cheek depth & -0.971 & -0.068 & -0.976 & -0.021 & -0.976 & 0.016 & -0.949 & -0.184 & -0.945 & 0.202 \\
\hline Eye diameter & -0.969 & -0.092 & -0.976 & -0.063 & -0.976 & 0.127 & -0.939 & -0.095 & -0.939 & 0.081 \\
\hline Inter orbital width & -0.976 & 0.106 & -0.980 & 0.109 & -0.983 & -0.094 & -0.957 & 0.159 & -0.967 & -0.059 \\
\hline Head width & -0.988 & 0.003 & -0.989 & 0.063 & -0.990 & -0.057 & -0.979 & -0.018 & -0.978 & 0.050 \\
\hline Standard length & -0.992 & 0.100 & -0.994 & 0.075 & -0.996 & -0.039 & -0.984 & 0.134 & -0.991 & -0.097 \\
\hline Head length & -0.994 & 0.012 & -0.995 & 0.027 & -0.996 & 0.016 & -0.987 & 0.034 & -0.987 & 0.098 \\
\hline Body depth & -0.985 & 0.073 & -0.987 & 0.109 & -0.990 & -0.078 & -0.970 & 0.082 & -0.976 & -0.033 \\
\hline Dorsal fin base & -0.974 & 0.165 & -0.981 & 0.149 & -0.985 & -0.109 & -0.961 & 0.173 & -0.973 & -0.146 \\
\hline Anal fin base & -0.971 & 0.125 & -0.977 & 0.129 & -0.979 & -0.108 & -0.938 & 0.219 & -0.952 & -0.212 \\
\hline Predorsal distance & -0.985 & -0.049 & -0.992 & -0.012 & -0.991 & 0.044 & -0.969 & -0.039 & -0.970 & 0.080 \\
\hline Prepectoral distance & -0.985 & 0.046 & -0.991 & -0.003 & -0.991 & 0.041 & -0.959 & 0.136 & -0.966 & 0.056 \\
\hline Prevental distance & -0.981 & 0.089 & -0.988 & 0.043 & -0.990 & -0.010 & -0.954 & 0.173 & -0.957 & 0.068 \\
\hline Preanal distance & -0.989 & 0.087 & -0.993 & 0.053 & -0.994 & -0.027 & -0.980 & 0.116 & -0.985 & -0.031 \\
\hline Caudal peduncle length & -0.916 & 0.069 & -0.936 & -0.173 & -0.936 & 0.299 & -0.889 & 0.104 & -0.888 & -0.339 \\
\hline Caudal peduncle depth & -0.967 & 0.167 & -0.979 & 0.096 & -0.982 & -0.071 & -0.957 & 0.183 & -0.967 & -0.135 \\
\hline Pharyngeal jaw length & -0.975 & -0.164 & -0.980 & -0.128 & - & - & -0.947 & -0.251 & - & - \\
\hline Pharyngeal jaw width & -0.964 & -0.223 & -0.969 & -0.200 & - & - & -0.932 & -0.295 & - & - \\
\hline Dental area length & -0.940 & -0.287 & -0.955 & -0.232 & - & - & -0.865 & -0.435 & - & - \\
\hline Dental area width & -0.959 & -0.211 & -0.967 & -0.139 & - & - & -0.927 & -0.256 & - & - \\
\hline Prp.Totl & 0.948 & 0.015 & 0.959 & 0.011 & 0.966 & 0.009 & 0.904 & 0.031 & 0.926 & 0.018 \\
\hline
\end{tabular}

Table 2. Principal component loadings of the first two axes of the log-transformed morphometrics for five PCAs performed on the Astatoreochromis specimens examined: PCA on Victoria (V) and Tanganyika (T) systems, PCA within the Lake Victoria system including (V) and excluding (V minus LPJ) the lower pharyngeal jaw measurements, and similarly for the Lake Tanganyika system (respectively $\mathrm{T}$ and $\mathrm{T}$ minus LPJ). 


\section{Mann-Whitney U-tests}

MWU-tests were used to further explore the differences observed in three comparisons: (1) the Lake Victoria (A. alluaudi) versus the Lake Tanganyika basin, (2) within the Lake Tanganyika basin between the Malagarazi and the Rusizi, and (3) within A. alluaudi between lakes Victoria and Kyoga (Greenwood's A. a. alluaudi) and lakes Edward, George, Kayanza, Nakavali, Nabugabo, and the Semliki River (Greenwood's A. a. occidentalis) (Table 3). For the Lake Victoria basin, only naturally occuring populations were included; hence the introduced populations from the Akagera system were omitted.

Significant differences between specimens from the Victoria and Tanganyika systems were present in six of the meristics and five of the morphometrics examined (Table 3).

\begin{tabular}{|l|ccc|}
\hline & $\begin{array}{c}\text { Victoria } \boldsymbol{~} \mathbf{s} . \\
\text { Tanganyika }\end{array}$ & Tanganyika & Victoria \\
\hline Meristics & $*$ & $\mathrm{~ns}$ & $\mathrm{~ns}$ \\
Upper jaw teeth (outer row) & $* * *$ & $*$ & $\mathrm{~ns}$ \\
Dorsal fin spines & $* * *$ & $\mathrm{~ns}$ & $\mathrm{~ns}$ \\
Dorsal fin soft rays & $\mathrm{ns}$ & $\mathrm{ns}$ & $\mathrm{ns}$ \\
Dorsal fin total rays & $* * *$ & $\mathrm{~ns}$ & $\mathrm{~ns}$ \\
Anal fin spines & $* * *$ & $\mathrm{~ns}$ & $\mathrm{~ns}$ \\
Anal fin soft rays & $* * *$ & $\mathrm{~ns}$ & $\mathrm{~ns}$ \\
Anal fin total rays & & & \\
Measurements & & & $\mathrm{ns}$ \\
\%SL & $* *$ & $\mathrm{~ns}$ & $\mathrm{~ns}$ \\
Body depth & $\mathrm{ns}$ & $*$ & $\mathrm{~ns}$ \\
Dorsal fin base & $*$ & $*$ & $\mathrm{~ns}$ \\
Anal fin base & $*$ & $* *$ & $\mathrm{~ns}$ \\
Predorsal distance & $* * *$ & $\mathrm{~ns}$ & $\mathrm{~ns}$ \\
Caudal peduncle length & $*$ & $\mathrm{~ns}$ & \\
Caudal peduncle depth & & & $\mathrm{ns}$ \\
\%HL & $\mathrm{ns}$ & $* * *$ & $* * *$ \\
Interorbital width & $\mathrm{ns}$ & $* * * *$ & ns \\
Pharyngeal jaw length & $\mathrm{ns}$ & $\mathrm{ns}$ & \\
Pharyngeal jaw width & $\mathrm{ns}$ & & \\
Dental area length & & $* * *$ \\
Dental area width & & & \\
\hline
\end{tabular}

Table 3. Results from Mann-Whitney U-tests, comparing meristics and measurements of specimens of a similar size class. Three comparisons were made (1) between the Lake Victoria $(n=27)$ and Tanganyika $(\mathrm{n}=80)$ systems [43.7-94.5 mm SL; $\mathrm{p}=0.316]$, (2) within the Tanganyika system between the Rusizi $(\mathrm{n}=43)$ and the Malagarazi $(\mathrm{n}=39)[43.7-111.3 \mathrm{~mm} \mathrm{SL} ; \mathrm{p}=0.464]$ and (3) within the Victoria system between lakes Victoria and Kyoga $(\mathrm{n}=12)$ and the remaining basins (lakes Edward, George, Kayanza, Nabugabo and Nakavali; $n=16$ ) [76.1-137.5 mm SL; $p=0.631]$. Only variables with a significant difference are listed. Significant levels are based on Bonferroni corrected values as follows: ns = not significant; $*=$ significant, $\mathrm{p} \leq 0.05 ; * *=$ highly significant, $\mathrm{p} \leq 0.01 ; * * *=$ very highly significant, $\mathrm{p} \leq 0.001$. 
Five meristics were very highly significantly different $(\mathrm{p} \leq 0.001)$, all relating to fin ray numbers. Of the morphometrics, one was very highly (caudal peduncle length) and one highly significantly (body depth) different. Within the Tanganyika basin, the Rusizi populations differed significantly from the Malagarazi population in one meristic (dorsal spine number), and in eight morphometrics, four of which (all LPJ measurements), differed very highly significantly (Table 3). No difference was observed in meristics between the different populations representing the former subspecies of $A$. alluaudi within the Lake Victoria basin, while three measurements (three LPJ measurements) were very highly significantly different.

While examining plots of the variables that differed significantly against standard length, we noted that some variables appeared to be size-related. Additional MWU-tests were thus performed on two size ranges (smaller and larger than $75 \mathrm{~mm} \mathrm{SL}$ ). Since few large specimens were available for Lake Victoria, specimens from the Upper and Middle Akagera populations, introduced from Lake Victoria (De Vos et al. 2001b), were included. Significant differences found among small specimens ( $<75 \mathrm{~mm} \mathrm{SL}$ ) from the Malagarazi and the Rusizi were absent in larger specimens (Table 4). In contrast, most of the differences found in larger specimens $>75 \mathrm{~mm}$ SL between the two former subspecies of A. alluaudi were greatly reduced or absent in smaller specimens (Table 4).

\begin{tabular}{|c|c|c|c|c|}
\hline & $\begin{array}{l}\text { Tanganyika } \\
\text { SL }<75 \mathrm{~mm}\end{array}$ & $\begin{array}{l}\text { Tanganyika } \\
\text { SL }>75 \mathrm{~mm}\end{array}$ & $\begin{array}{c}\text { Victoria } \\
\mathrm{SL}<75 \mathrm{~mm}\end{array}$ & $\begin{array}{c}\text { Victoria } \\
\text { SL }>75 \mathrm{~mm}\end{array}$ \\
\hline \multicolumn{5}{|l|}{$\% \mathrm{HL}$} \\
\hline Lachrymal depth & $*$ & ns & ns & ns \\
\hline Snout length & $*$ & ns & ns & \\
\hline Cheek depth & $* * *$ & ns & ns & ns \\
\hline Inter-orbital width & $*$ & ns & $*$ & $\mathrm{~ns}$ \\
\hline Head width & $\mathrm{ns}$ & ns & $*$ & $*$ \\
\hline Pharyngeal jaw length & $* * *$ & ns & ns & $* * *$ \\
\hline Pharyngeal jaw width & $* * *$ & ns & $* * *$ & $* * *$ \\
\hline Dental area length & $* * *$ & ns & ns & $* * *$ \\
\hline Dental area width & $* *$ & ns & $*$ & $* *$ \\
\hline \multicolumn{5}{|l|}{$\% \mathrm{SL}$} \\
\hline Head length & $*$ & ns & ns & ns \\
\hline Pre-dorsal distance & $* *$ & ns & ns & $* *$ \\
\hline Dorsal fin base & $\mathrm{ns}$ & ns & $*$ & $* *$ \\
\hline Caudal peduncle length & & & ns & $* * *$ \\
\hline Anal fin base & ns & $*$ & ns & ns \\
\hline
\end{tabular}

Table 4. Result from Mann-Whitney U-tests, comparing measurements of specimens of two size classes, $\mathrm{SL}<75 \mathrm{~mm}$ and SL $>75 \mathrm{~mm}$. Four comparisons were made (1-2) within the Tanganyika system between the Rusizi $(\mathrm{n}=26, \mathrm{SL}<75 \mathrm{~mm}$ and $\mathrm{n}=14, \mathrm{SL}>75 \mathrm{~mm})$ and the Malagarazi $(\mathrm{n}=31, \mathrm{SL}<75$ $\mathrm{mm}$ and $\mathrm{n}=9$, SL $>75 \mathrm{~mm}$ ) and (3-4) within the Victoria system between lakes Victoria-Kyoga and the Akagera system $(\mathrm{n}=37$, SL $<75 \mathrm{~mm}$ and $\mathrm{n}=20$, SL $>75 \mathrm{~mm}$ ), and the remaining basins (lakes Edward, George, Kayanza, Nabugabo and Nakavali; $\mathrm{n}=14, \mathrm{SL}<75 \mathrm{~mm}$ and $\mathrm{n}=13$, SL $>75 \mathrm{~mm}$ ). Only variables with a significant difference are listed. Significant levels are based on Bonferroni corrected values as follows: $\mathrm{ns}=$ not significant; $*=$ significant, $\mathrm{p} \leq 0.05 ; * *=$ highly significant, $\mathrm{p} \leq 0.01$; $* * *=$ very highly significant, $\mathrm{p} \leq 0.001$. 
From the PCAs and MWU-tests presented above, we conclude that the Lake Victoria basin and the Tanganyika basin populations represent different species. Within the Lake Tanganyika basin, we found little support for species status of $A$. vanderhorsti and $A$. straeleni, and propose the synonymy of $A$. vanderhorsti. An updated definition of the genus Astatoreochromis and a redescription of the two valid species, A. alluaudi and A. straeleni, is given below.

\section{Class Actinopterygii \\ Division Teleostei \\ Order Perciformes}

Family Cichlidae Bonaparte, 1835

Genus Astatoreochromis Pellegrin, 1904

Astatoreochromis Pellegrin, 1904

The genus Astatoreochromis can be distinguished from 'Haplochromis' by the possession of three to seven anal spines ( $v s$. three in 'Haplochromis'); 16 to 20 dorsal fin spines (vs. 13-16 in 'Haplochromis'), a rounded caudal fin ( $v s$. sometimes rounded, obliquely truncate, truncate, subtruncate or emarginated in 'Haplochromis'), a large number of anal ocelli arranged in three to five horizontal rows ( $v s$. few anal ocelli arranged in one or two rows in 'Haplochromis'), and a less marked sexual dimorphism in colour pattern (vs. a marked sexual dimorphism in 'Haplochromis').

Astatoreochromis alluaudi Pellegrin, 1904

Fig. 5

Alluaud's haplo, local names: 'Ifuro muhunde, Ifuro y'itanza, Ifuro y'ikomagi' where 'Ifuro' is the local name given to all haplochromine species (Upper Akagera system, Burundi), 'Icyasamyi', 'Ikaje' or 'Nyiramuhundi' (Middle Akagera system, Rwanda).

Astatoreochromis alluaudi Pellegrin, 1904: 385.

Astatoreochromis alluaudi alluaudi Greenwood, 1959: 174, figs 1-3.

Astatoreochromis alluaudi occidentalis Greenwood, 1959: 174-175, figs 2-3.

\section{Diagnosis}

Astatoreochromis alluaudi can be distinguished from A. straeleni by the possession of 4-7 anal spines (usually 5-6) vs. 3-4 (usually 3), 17-19 dorsal spines [rarely 16 (f2) or 20 (f2)] vs. 16-18 [exceptionally $19(\mathrm{fl})]$.

\section{Etymology}

Named after Charles A. Alluaud, who collected the type specimens.

\section{Type material}

\section{Lectotype}

MNHN 1904.137, Kavirondo Gulf, Lake Victoria, Kenya, designated by Greenwood (1959: 167).

\section{Paralectotypes}

MNHN 1904.138-139, BMNH 1904.6.281, same data as lectotype.

\section{Specimens examined}

KENYA: MNHN 1904.137, lectotype, 121.7 mm SL, Kavirondo Gulf Lake Victoria, coll. Alluaudi; BMNH 1904.6.28.1, paralectotype, $116.0 \mathrm{~mm}$ SL, same data as lectotype; MNHN 1904.138-139, 
paralectotypes, 92.8-113.8 mm SL, same data as lectotype. UGANDA: AMNH 216258 (3 specimens), 53.5-70.7 mm SL, Lake Nabugabo, coll. L.J. Chapman \& C.A. Chapman, 19 May 1994; BMNH 1964.7.1.109, 85.5 mm SL, Lake Nabugabo, coll. Cambridge University; BMNH 1933.2.23.146 (11 specimens), 55.2-137.5 mm SL, Lake Nakavali, coll. E. Worthington; BMNH 1958.12.5.74-75, 63.8121.4 mm SL, Lake Nakavali, coll. C. Pitman; BMNH 1972.6.5.23-25, 44.8-101.6 mm SL, Lake George, coll. I. Dunn; BMNH 1933.2.23.137-141, 61.4-79.8 mm SL, Lake Edward, coll. E.Worthington; BMNH 1929.1.24.4, 87.8 mm SL, Lake Kyoga, coll. E. Worthington; BMNH 1929.1.24.278, 70.9 mm SL, Lake Kyoga, coll. E. Worthington; MRAC A5.42.P.2-5, 66.3-128.4 mm SL, Lake Kayanza, Kasese factory, coll. M. Marquet, 22 Oct. 2005; MRAC 14862-3, 95.9-111.1 mm SL, Nyanza, Lake Victoria, coll. D.E. Bayon; MRAC 90.035.P.12, 124.2 mm SL, Gaba near Kampala, Lake Victoria, 0 ${ }^{\circ} 15^{\prime} \mathrm{S}-$ $32^{\circ} 28^{\prime}$ E, coll. D. Nyeko, 18 Mar. 1990. DEMOCRATIC REPUBLIC OF CONGO: MRAC 66003, 51.3 mm SL, Semliki River, Ishango, coll. H. Damas. TANZANIA: MRAC 81.30.P.4-5, 94.5-96.5 mm SL, Mwanza gulf, Lake Victoria, collector. HEST-Collection, 1977-1980; MRAC 90.16.P.1-3, 73.7-79.7 mm SL, Kiboko, Lake Victoria. BURUNDI: MRAC 81.P.47.512-535, 63.7-112.7 mm SL, Nyagisozi, Lake Rweru, 02 ${ }^{\circ} 8^{\prime}$ S - 30¹8’ E, coll. G. Ntakimazi, 6 May 1981; MRAC 93.149.P.27, 71.7 mm SL, Yaranda, maison Turquien, Lake Cohoha, 02³2' S - 3006’ E, coll. J. Snoeks et al., 28-29 Jul. 1993; MRAC 93.149.P.41, 83.8 mm SL, Yaranda, maison Turquien, Lake Cohoha, 02³2' S - 3006' E, coll. J. Snoeks et al., 28-29 Jul. 1993; MRAC 93.149.P.28-40, 57.2-121.6 mm SL, Lake Rwihinda, 'lac aux oiseaux', 02 $2^{\circ} 35^{\prime} \mathrm{S}-30^{\circ} 06^{\prime} \mathrm{E}$, coll. J. Snoeks et al., 9-10 Aug. 1993. RWANDA : MRAC 87.11.P.28272828, 73.6-83.4 mm SL, Lake Hago, Akagera park, coll. L. De Vos, 12 Oct. 1986; MRAC 87.P. 11.2852, MRAC 87.11.P.2852-55, 61.5-71.9 mm SL, Lake Mpanga, 'à l'entrée du parc Akagera' coll. L. De Vos, 5 Nov. 1986; MRAC 86.01.P.1955, 99.2 mm SL, Lake Birengero, Akagera park, coll. L. De Vos, 14 Sep. 1985.

\section{Redescription}

Based on 87 specimens including lectotype and three paralectotypes. Morphometrics and meristics are given in Table 5. Small to medium-sized species [maximum size, $163 \mathrm{~mm} \mathrm{SL}$ (Greenwood 1959)] with moderately compressed body; dorsal head profile fairy steeply sloping, straight or decurved, becoming concave in large individuals. Mouth horizontal or slightly oblique. Jaws equal anteriorly or lower somewhat projecting; posterior tip of maxilla reaching, or almost reaching, vertical to anterior orbital margin. Gill rakers short and stout; generally 8 or 9 [7(f1), 8 (f30), 9 (f49), 10 (f7)] on the lower limb of the first gill-arch. Flank scales around lateral line ctenoid, elsewhere cycloid; generally 29-32 longitudinal line scales, excluding the small scales on caudal fin base [26 (f1), 27(f2), 28 (f5), 29 (f8), 30 (20), 31 (f29), 32 (f14)]; cheek with 3 (f24), 4 (f57) or 5 (f5) series of scales; scales between pectoral and pelvic fins 4 (f35), 5 (f40) or 6 (f8) [rarely 3 (f1)]. Dorsal fin spines 17-19 [rarely 16 (f2) or 20 (f2)], soft rays 7 (f29) or 8 (f51) [occasionally 6 (f2) or 9 (f5)]. Anal fin spines 4-7 [(4 (f7), 5 (f63), 6 (f17) and 7 (f2)], rays 6 (f9), 7 (f56) or 8 (f20) [rarely 9 (f2)]. Pectoral fin rays 13 (f32) or 14 (f54) [rarely 15 (f1)]. Caudal fin rounded. Posteriormost teeth in outer row of upper jaw unicuspid. In small specimens, outer row teeth unequally bicuspid and relatively stout (occasionally only stout unicuspid teeth in small specimens) becoming a mixture of weakly bicuspid and unicuspid in large specimens. 28-48 outer row teeth in upper jaw and 20-42 outer row teeth in lower jaw with numbers increasing with size, 1 or 2 (occasionally 3 ) inner rows of small tricuspid or occasionally unicuspid teeth in both lower and upper jaws. LPJ triangular, longer than, or almost as long as, wide (LPJ width 78.1-108.5\% of LPJ length); lateral teeth in the posterior rows slender and cuspidate, the central two to four (occasionally six) rows with a mixture of molariform (anterior part of the dentigerous area) and enlarged but cuspidate teeth. The specimens from Lake Victoria have a more massive LPJ and a greater proportion of molariform teeth compared to the similarly sized specimens from other lakes and rivers in the Victoria basin. 


\section{Colour pattern of live specimens}

See Fig. 5 for general appearance. Anteriorly and dorsally grey yellowish, posterior-ventrally grey greenish to bluish. A dark band, continuous with lachrymal stripe, runs obliquely backwards through, or a little behind, the eye to near the gill opening. Lower jaw faint grey bluish. Fins grey yellowish, dorsal fin somewhat darker and with blackish spots on soft part; caudal fin with similar spots, pelvic blackish distally; anal fin of specimens (males and females) larger than $80 \mathrm{~mm}$ SL with 2-3 horizontal rows of bright orange-yellow ocelli. In specimens less than $80 \mathrm{~mm} \mathrm{SL}$, anal ocelli may be absent or hardly visible. According to Greenwood (1959), sexual dimorphism is less marked in this species than in other haplochromine cichlids and the colour pattern of breeding males resembles that of females except that the soft dorsal fin is more densely spotted, the spinous dorsal and entire caudal fin are suffused with maroon, and the cephalic marking are more intense than in females.

\section{Colour pattern of preserved specimens}

General appearance greyish-brown to brown, lighter ventrally; five or six dark transverse bars often interrupted ventrally on the flanks (lacking in some specimens). No mid-lateral band present. A vertical,

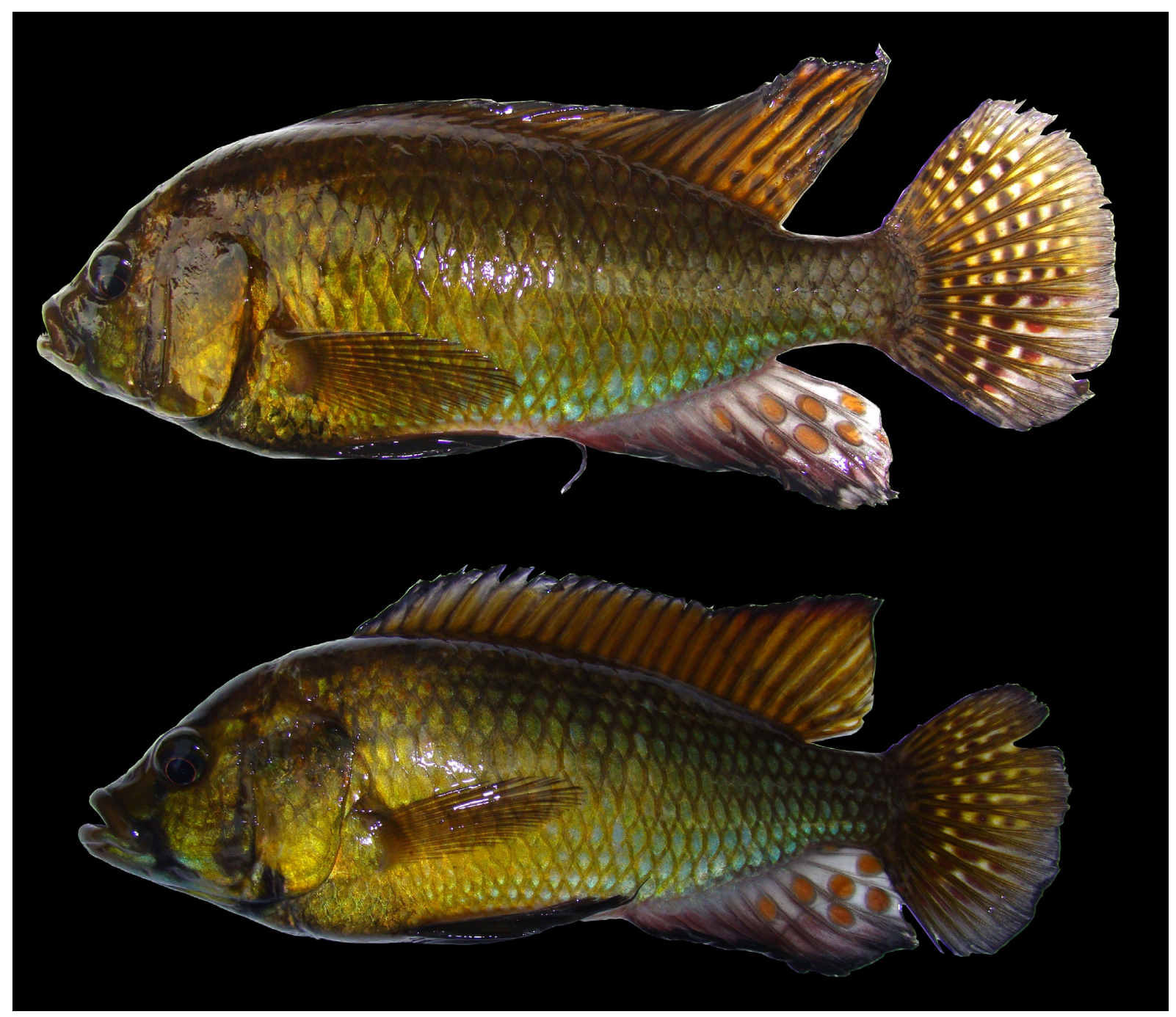

Fig. 5. Adult $\widehat{\jmath}$ of Astatoreochromis alluaudi Pellegrin, 1904 caught on 15 Dec. 2012 at Kumana village, Nyagisozi zone, Lake Rweru, Upper Akagera (Rwanda), 115,3 mm SL and 100,4 mm SL not catalogued. (Photographs by GB) 
or posteriorly directed, blackish bar below the eye, runs to posterior corner of mouth, occasionally extending onto lower jaw. Blackish dots arranged in interrupted horizontal rows on soft dorsal fin and in interrupted vertical rows on caudal fin; these are strongly marked in large males. Edge of fins dark to blackish, anal ocelli in males, when present dark grey.

\section{Distribution}

Known from lakes Edward, Victoria, Kyoga, George, Nakavali and Kachira, and the rivers and streams associated with these lakes, including the Semliki (Greenwood 1959). The species has been introduced into many areas of East Africa for biological mollusc control (Greenwood 1965b; Welcomme 1988) and now has a widespread distribution within the Victoria basin (Kenya, Uganda \& Tanzania including the Upper Akagera basin in the Bugesera depression (Burundi \& Rwanda)). Slootweg (1989) discussed the possibility of the introduction of $A$. alluaudi into northern Cameroon (Benue River basin), which indeed took place (Vreven et al. 2007). There are no reports that the introduction of this species in the Congo Republic, the Democratic Republic of Congo, the Republic of Central Africa and Zambia (Welcomme 1988) has succeeded.

\section{Ecology}

According to Greenwood (1959), A. alluaudi is not confined to a particular type of substrate and is ubiquitous in all areas where the water is less than $20 \mathrm{~m}$ deep. It also occurs in papyrus swamps and feeds mainly on molluscs. Ntakimazi (1985) confirmed the occurrence of the species in papyrus swamps in Lake Rweru, Bugesera depression (Burundi \& Rwanda). However, he did not find any shell fragments of snails in the gut contents of 80 specimens, but instead found a large amount of organic debris, algae, fish remains and benthic invertebrates. He concluded that $A$. alluaudi might be an omnivorous species that switches to the most abundant food source in its environment. He noticed, however, that the molariform teeth of the lower pharyngeal jaw are well developed, and suspected they are instrumental in crushing the exoskeletons of aquatic invertebrates and vegetal debris.

\section{Reproduction}

The species is a mouth-brooder. Most of the females caught in December 2012 in Lake Rweru in Burundi had fry in their mouth. Though its breeding period is not well documented, the species may reproduce at the end of the short rain season from November to December. Whether this is the only reproductive season cannot be determined from our data.

Astatoreochromis straeleni (Poll, 1944)

Fig. 6

Bluelip haplo, local names: 'Ifuro' (common name for all haplochromine species in the Malagarazi), 'Ikijori' (name for all haplochromine species in the Rusizi basin) or 'Inunge' (used by fishermen from the Rusizi basin who distinguish this species from other haplochromine species).

Haplochromis straeleni Poll, 1944: 10, figs 9-10.

Haplochromis vanderhorsti Greenwood, 1954: 405-413, figs 1-3.

Astatoreochromis straeleni - Poll 1974: 100.

Astatoreochromis vanderhorsti - Greenwood 1979: 286.

\section{Diagnosis}

Astatoreochromis straeleni can be distinguished from A. alluaudi by the possession of 3-4 anal spines (usually 3) vs. 4-7 (usually 5-6); 16-18 [exceptionally 19 (f1)] dorsal spines vs. 17-19 dorsal spines [rarely 16 (f2) or 20 (f2)]. 


\section{Etymology}

Named in honour of Prof. V. Van Straelen, Director of the Musée du Congo Belge, Tervuren, Belgium from 1926 to 1954.

\section{Type material}

\section{Holotype}

IRSNB 75, Rivière Lukuga, Région d'Albertiville, DRC.

\section{Specimens examined}

Astatoreochromis straeleni: DEMOCRATIC REPUBLIC OF CONGO: IRSNB 75, $78.9 \mathrm{~mm}$ SL, holotype, Lukuga River, Albertville region, coll. Dr Poyer (purchased); MRAC 107795, 81.2 mm SL, Lukuga, 'près du lac d'Arbertville', coll. Exploration hydrobiologique du lac Tanganyika, 30 Oct. 1946; MRAC 84.2.P.1-2, 51.2-54.0 mm SL, Kiliba River, coll. M. Baluku, 17 Nov. 1982. BURUNDI: MRAC 95.98.P.199, 81.4 mm SL, Kimirabasore, Kajeke swamps, coll. L. De Vos, 9 Feb. 1995; MRAC 73.68.P.165-170, 54.6-71.3 mm SL, small branch of the Rusizi River, near Lake Tanganyika, coll. Brichard, May 1973; MRAC 73.68.P.171, 82.9 mm SL, Rusizi swamps near Lake Tanganyika, coll. Brichard, 1973; MRAC 73.68.P.172-173, 50.3-65.7 mm SL, 'Port de Bujumbura', coll. Brichard, Feb. 1972; MRAC 91.62.P.1794, $79.9 \mathrm{~mm}$ SL, Gatumba swamps, $3^{\circ} 05^{\prime} \mathrm{S}-2^{\circ} 15^{\prime}$ E, coll. L. De Vos \& P. Weiler, 13 Aug. 1991; MRAC 91.89.P.33, 96.4 mm SL, Gatumba swamps, 305' S - 29 $15^{\prime}$ E, coll. P. Weiler, 8 Sep. 1991 91.89.P.83-92, 66.1-103.5 mm SL, Gatumba swamps, 305’ S - 29¹5’ E, coll. P. Weiler, 1-21 Sep. 1991; MRAC A9.13.P.75-105, 55.7-75.8 mm SL, Gatumba swamps, 03²0'18.6” S - 029¹3'42.7” E, coll. Banyankimbona, 28 Jan.-11 Feb. 2009; MRAC B1.3.P.1-12, 55.5-88.4 mm SL, Gatumba swamps, 03²0’21.6” S - 029 ${ }^{\circ} 13^{\prime} 56.9^{\prime \prime}$ E, coll. G. Banyankimbona, 07 Nov. 2010, MRAC B0.3.P.5-7, 57.2$74.2 \mathrm{~mm}$ SL, Kideheri pool, Rusizi basin, Karwema village, 0306'15.0” S - 029 15'27.8” E, coll. G. Banyankimbona, 6 Dec. 2009; MRAC B0. 3.P.8-10, 72.4-75.0 mm SL, Kinake pool, Rusizi basin, Nyamitanga village, $03^{\circ} 03^{\prime} 52.9^{\prime \prime} \mathrm{S}-029^{\circ} 15^{\prime} 40.2^{\prime \prime} \mathrm{E}$, coll. G. Banyankimbona, 9 Dec. 2009; MRAC B0.3.P.19-20, 61.7-65.6 mm SL, Kameme pool, Rukoko natural reserve, 03¹1'59.4" S - 029¹3'47.8" E, coll. G. Banyankimbona, 7 Dec. 2009.

Astatoreochromis vanderhorsti: BURUNDI: MRAC A9.13.P.55-74, 61.3-85.7 mm SL, Malagarazi River, Butezi village, 035'01,64” S - 030'15'22,3” E, coll. G. Banyankimbona, 13-15 Dec. 2008; MRAC B0.3.P.1, 59.0 mm SL, Malagarazi river, Mutwana village, 0351'25.2" S - 030¹7'53.5" E, coll. G. Banyankimbona, 31 Jul. 2009; MRAC B0.3.P.2, 72.2 mm SL, Malagarazi River, Butezi village, $03^{\circ} 55^{\prime} 01,64$ ” S - 030 ${ }^{\circ} 15^{\prime} 22,3$ ” E, coll. G. Banyankimbona, 1-2 Aug. 2009; MRAC B0.3.P.3, $62.5 \mathrm{~mm}$ SL, Mazimero River, Nyamateke swamp, Gasunu village, 0353'28.4” S - 030¹3’03.7” E, coll. G. Banyankimbona, 5 Aug. 2009; MRAC 91.30.P.558, 76.5 mm SL, Butezi, fishermen's village,

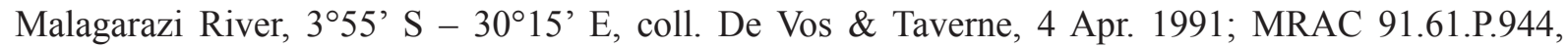
$81.7 \mathrm{~mm}$ SL, Butezi, fishermen's village, Malagarazi River, 355' S - 30¹5' E, coll. Taverne, Jun. 1991; MRAC 91.30.P.559, $43.7 \mathrm{~mm}$ SL, Nyamiviro rivulet, affl. Malagarazi, $6 \mathrm{~km}$ on road from Kinyinya to Makebuko, 337' S - 30²0' E, coll. L. De Vos \& L. Taverne, 5 Apr.1991; MRAC 91.62.P.1795-1796, 66.1-70.2.5 mm SL, Nyamiviro rivulet, affl. Malagarazi, $6 \mathrm{~km}$ on road from Kinyinya to Makebuko, $3^{\circ} 37^{\prime} \mathrm{S}$ - 30²0’ E, coll. De Vos \& Taverne, 6 Apr. 1991; MRAC 96.31.P.1425, 64.0 mm SL, Nyamiviro rivulet, affl. Malagarazi, $6 \mathrm{~km}$ on road from Kinyinya to Makebuko, $3^{\circ} 37^{\prime} \mathrm{S}-30^{\circ} 20^{\prime} \mathrm{E}$, coll. L. De Vos \& L. Taverne, 3 Jun. 1992. TANZANIA: BMNH1953.11.4, holotype, $111.3 \mathrm{~mm}$ SL, from Katare swamps, Malagarazi basin, coll. G.J. Lockley, 11 Apr. 1953; BMNH1953.11.4 (18 specimens), paratypes, 59.2$79.8 \mathrm{~mm} \mathrm{SL}$, same data as holotype. 


\section{Description}

Based on the holotype and 85 specimens. Morphometrics and meristics are given in Table 5. Small to medium sized species ( $\max 111.3 \mathrm{~mm} \mathrm{SL}$ ) with moderately compressed body. Snout pointed or slightly concave. Eye diameter as long as, or shorter than, interorbital width. Caudal peduncle variable, ranging from somewhat longer than deep to just slightly deeper than long. Gill rakers on lower part of the anterior arch thick and stout, 8-10 [8 (f33), 9 (f41), 10 (f11)], last three or four reduced to small nubs. Upper and lower jaws with 1-3 inner rows of tricuspid teeth. Outer series in both jaws composed of unequally bicuspid and sometimes compressed teeth, only slightly cuspidate or conical in the posteriormost part of both jaws. Tooth number of outer rows increases with size: 32-56 in upper jaw and 23-44 in lower jaw. Flank scales around lateral line ctenoid, elsewhere cycloid; generally 29-32 longitudinal line scales, excluding the small scales on caudal fin base [28 (f3), 29 (f10), 30 (29), 31 (f26), 32 (f14), 33 (f2)]; cheek with 3 (f49) or 4 (f35) [rarely 5 (f1)] scale rows; scales between pectoral and pelvic fins 4(f51) or 5 (f30) [rarely 3 (f1) or 6 (f2)]. Dorsal fin spines 16-18 [exceptionally 19 (f1)], soft rays 8-10 [8 (f8), 9

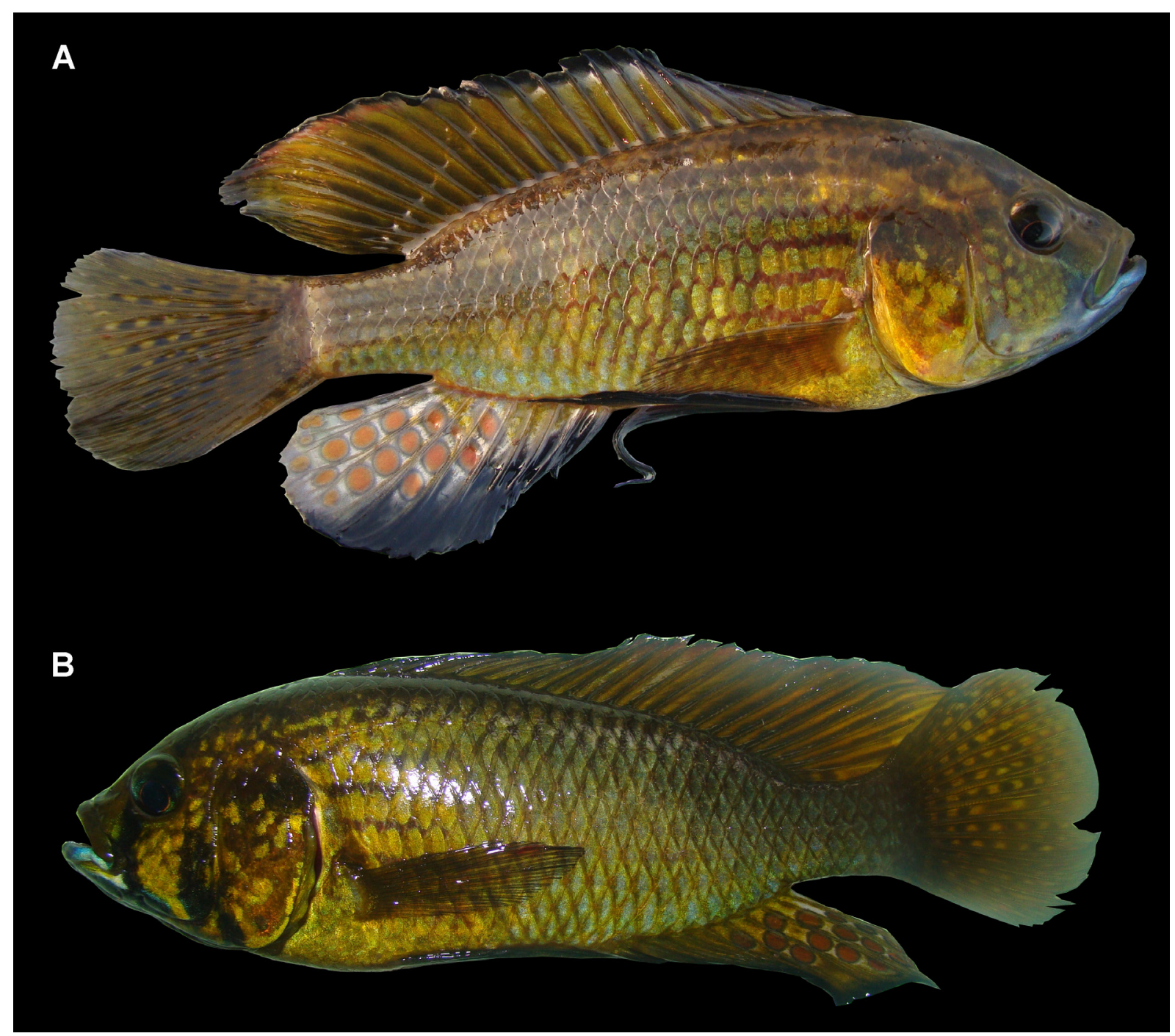

Fig. 6. Adult $\widehat{\partial} \widehat{\partial}$ of Astatoreochromis straeleni (Poll, 1944). A. MRAC A9-13-P-555, 70.6 mm SL, collected on 13 Dec. 2008 in the Malagarazi. B. MRAC B1-3-P-1, 88.3 mm SL, collected on 7 Jan. 2011 in the Rusizi. (Photographs by GB) 
(f52), 10 (26)]. Anal fin spines 3-4 (usually 3), rays 8 (f19), 9 (63) or 10 (f4). Pectoral fin rays 13 (f47) or 14 (f26) [rarely 11 (f1) or 12 (f2)]. Caudal fin rounded. LPJ triangular, longer than, or almost as long as, wide (LPJ width 83.3-102.8 \% of LPJ length); its teeth in the lateral external rows slender and cuspidate, the central two to four rows with a mixture of molariform (anterior part of the dentigerous area) and enlarged but cuspidate teeth.

\section{Colour pattern of live specimens}

See Fig. 6 for general appearance. Dorsally and dorso-laterally dark grey-yellowish, orange yellowish on opercle, upper part of cheek, chest and belly. Lips and lower part of cheek iridescent blue. Fins orange yellowish, dorsal with red edge, more pronounced posteriorly. Anal fin with 3-5 horizontal rows of bright orange-yellow ocelli. Females with similar but smaller ocelli. Caudal fin with black dots arranged in 6-8 more or less regular vertical rows. While general appearance remains the same, live colour pattern appears influenced by characteristics of the water in which the individuals live. Rusizi specimens caught in water with a high conductivity (more than $250 \mu \mathrm{s} / \mathrm{cm}$ ) and muddy blackish bottom substrate in the Gatumba swamps near Lake Tanganyika during the rainy season have a darker colour pattern (Fig. 6B). Specimens caught in the pools associated with the Rusizi River more to the north and in marginal vegetation of the Malagarazi River are generally lighter coloured (Fig. 6A).

\section{Colour pattern of preserved specimens}

General appearance dark brown for recently preserved specimens turning lighter grey or dark grey after a couple of years of preservation. Fins dark grey, edge of anal and anterior part of dorsal and pelvic fins dark brown to blackish. No mid-lateral band present. A large blackish blotch at upper posterior end of gill cover, may be vague in some specimens. A blackish vertical bar below, or behind, the eye in all recently preserved specimens; this bar may disappear in specimens kept for some time in alcohol. Blackish dots arranged in interrupted horizontal rows in posterior portion of soft dorsal fin and in interrupted vertical rows in caudal fin. Anal ocelli always present but less visible distally, where anal fin is dark brown to blackish.

\section{Distribution}

Known from the Rusizi, Lukuga and Malagarazi basins and from the Luiche, a small affluent of Lake Tanganyika just north of the Malagarazi River delta. The species apparently also enters the lake as it was collected by Brichard in 1973 from the harbour of Bujumbura; in addition, De Vos et al. (2001) mentioned its presence at the harbour of Ujiji near Kigoma in Tanzania. Its presence in other affluents of Lake Tanganyika needs to be confirmed.

\section{Ecology}

Astatoreochromis straeleni is primarily a riverine species (Greenwood 1954; Poll 1956, 1974), prefering clear water (pers. obs. GB). In the Malagarazi basin, no specimen was found in the main channel. The most important catch was made during the rainy season when specimens were caught in swampy flooded areas. The species was also caught in marginal vegetation of the Mazimero River, a small affluent of Malagarazi, with a high water transparency. In the Rusizi basin, the species was mainly caught in the Gatumba swamps where it is more abundant than in the Malagarazi basin; here also it was found mainly in vegetated areas with clear water. It was also common in the small swampy pools associated with the Rusizi River. The species was never caught in nor reported by the local fishermen from the main course of the Rusizi River. Greenwood (1954) reported the species to feed mainly on snails, ostracods and insects in the Malagarazi basin. Examination of stomach and gut content of 12 recently collected specimens (January 2011) from the Rusizi found snails (entire and fragmented shells) together with adult insect fragments (wings) and other invertebrate remains in four specimens. Two 
BANYANKIMBONA G. et al., Revision of the cichlid genus Astatoreochromis

\begin{tabular}{|c|c|c|c|c|c|c|}
\hline \multirow[b]{3}{*}{ MORPHOMETRICS } & \multicolumn{3}{|c|}{ A. straeleni } & \multicolumn{3}{|c|}{ A. alluaudi } \\
\hline & \multirow[t]{2}{*}{ Holotype } & \multicolumn{2}{|c|}{86 specimens } & \multirow[t]{2}{*}{ Lectotype } & \multicolumn{2}{|c|}{87 specimens } \\
\hline & & $\operatorname{Mean} \pm$ SD & Range & & Mean \pm SD & Range \\
\hline Standard Length & 78.9 & $70.0 \pm 11.6$ & $43.7-111.3$ & 121.7 & $81 \pm 21.4$ & $44.8-137.5$ \\
\hline \multicolumn{7}{|l|}{ As \% of standard length } \\
\hline Head length & 36.2 & $34.7 \pm 1.3$ & $31.8-38.1$ & 33.4 & $35.3 \pm 1.4$ & $31.7-39.2$ \\
\hline Body depth & 37.3 & $35.5 \pm 1.8$ & $30.9-39.7$ & 36.9 & $36.5 \pm 1.5$ & $33.5-41.1$ \\
\hline Dorsal fin base & 57.8 & $58.2 \pm 2.2$ & $52.7-63.6$ & 59.5 & $57.4 \pm 1.9$ & $52.9-61$ \\
\hline Anal fin base & 23.3 & $23.7 \pm 1.2$ & $21.2-26.4$ & 27.0 & $24.7 \pm 1.2$ & $21.2-27.9$ \\
\hline Predorsal distance & 35.1 & $35.4 \pm 1.6$ & $31.6-38.0$ & 35.2 & $36.6 \pm 1.7$ & $31.1-41.1$ \\
\hline Prepectoral distance & 40.9 & $37.5 \pm 1.8$ & $33.4-45.4$ & 34.8 & $37.5 \pm 1.7$ & $33.3-41.1$ \\
\hline Preventral distance & 48.5 & $42.8 \pm 2.5$ & $39.8-54.9$ & 41.6 & $43.1 \pm 1.7$ & $40.1-48.3$ \\
\hline Preanal distance & 69.3 & $66.1 \pm 1.7$ & $61.7-71.0$ & 66.1 & $65.3 \pm 1.8$ & $62.4-71.9$ \\
\hline Caudal peduncle length & 11.5 & $13.2 \pm 1.0$ & $10.4-15.8$ & 14.0 & $12.6 \pm 1.2$ & $9.7-15.2$ \\
\hline Caudal peduncle depth & 12.4 & $12.3 \pm 0.5$ & $10.9-13.3$ & 13.1 & $11.8 \pm 0.6$ & $10.4-13.5$ \\
\hline \multicolumn{7}{|l|}{ As \% of head length } \\
\hline Lacrymal depth & 13.3 & $14.1 \pm 0.9$ & $11.0-16.6$ & 15.8 & $14.3 \pm 1.2$ & $12.2-17.4$ \\
\hline Snout length & 30.1 & $27.5 \pm 1.5$ & $24.6 \pm-31.6$ & 29.8 & $28.7 \pm 1.9$ & 24.1-31.6 \\
\hline Lower jaw length & 40.6 & $40.5 \pm 1.9$ & $34.2-45.9$ & 38.7 & $40.8 \pm 2.2$ & $35.3-47.9$ \\
\hline Premaxillary pedicel length & 27.3 & $27.5 \pm 1.5$ & $24.3-31.4$ & 27.6 & $26.9 \pm 1.4$ & $22.2-29.3$ \\
\hline Cheek depth & 25.5 & $23.6 \pm 2.1$ & $17.7-28.2$ & 25.4 & $23.9 \pm 2.1$ & $19.1-28.2$ \\
\hline Eye diameter & 28.0 & $29.0 \pm 1.8$ & $24.5-34.9$ & 24.6 & $27.7 \pm 2.3$ & $23.5-33.3$ \\
\hline Inter-orbital width & 25.9 & $27.5 \pm 1.8$ & $23.6-32.1$ & 30.8 & $27.8 \pm 1.6$ & $23.6-32.1$ \\
\hline Head width & 42.0 & $43.7 \pm 1.7$ & $39.6-47.7$ & 46.1 & $43.8 \pm 1.8$ & $40.3-49.2$ \\
\hline Pharyngeal jaw length & - & $34.0 \pm 2.1$ & $29.5-39.9$ & 36.2 & $34.2 \pm 2.0$ & $30.2-39.5$ \\
\hline Pharyngeal jaw width & - & $30.9 \pm 2.4$ & $26.9-37.6$ & 36.9 & $32.9 \pm 2.6$ & $28.7-40.6$ \\
\hline Dental area length & - & $20.2 \pm 2.2$ & $16.3-25.7$ & 24.4 & $21.6 \pm 2.1$ & $17.1-27.6$ \\
\hline Dental area width & - & $21.9 \pm 1.4$ & $18.5-25.6$ & 22.7 & $23.5 \pm 1.5$ & $19.0-27.7$ \\
\hline \multicolumn{7}{|l|}{ As \% of head width } \\
\hline Inter-orbital width & 61.7 & $63.5 \pm 3.9$ & $56.4-72.7$ & 66.8 & $63.5 \pm 3.7$ & $55.1-73.1$ \\
\hline \multicolumn{7}{|l|}{$\begin{array}{l}\text { As \% of caudal peduncle } \\
\text { length }\end{array}$} \\
\hline Caudal peduncle depth & 107.7 & $2.0 \pm 8.0$ & $76.6-125.0$ & 93.5 & $93.7 \pm 10.5$ & 71.4-122.4 \\
\hline \multicolumn{7}{|l|}{ MERISTICS } \\
\hline Upper jaw teeth (outer row) & 41 & \multicolumn{2}{|c|}{$32-56$} & 32 & \multicolumn{2}{|c|}{$28-48$} \\
\hline Lower jaw teeth (outer row) & 34 & \multicolumn{2}{|c|}{$23-44$} & 30 & \multicolumn{2}{|c|}{$20-42$} \\
\hline Upper inner teeth rows & 2 & \multicolumn{2}{|c|}{$1-3$} & 2 & \multicolumn{2}{|c|}{$1-3$} \\
\hline Lower inner teeth rows & 2 & \multicolumn{2}{|c|}{$1-3$} & 2 & \multicolumn{2}{|c|}{$1-3$} \\
\hline Gill rakers & $8-1-2$ & \multicolumn{2}{|c|}{$(8-11)-1-(1-3)$} & $9-1-2$ & \multicolumn{2}{|c|}{$(7-10)-1-(1-4)$} \\
\hline Dorsal fin formula & $\mathrm{XVIII} / 8$ & \multicolumn{2}{|c|}{ XVI-XIX / 8-10 } & VXVIII/8 & XVI- $>$ & $X / 6-9$ \\
\hline Anal fin formula & $\mathrm{III} / 9$ & III-I & & $\mathrm{V} / 7$ & IV-V & I / 6-9 \\
\hline Pectoral fin rays & 13 & & & 14 & & 15 \\
\hline Longitudinal line scales & 29 & & & 30 & & 32 \\
\hline Lateral line scales & $19 / 7$ & $17-2$ & & $17 / 12$ & $16-2$ & $/ 7-13$ \\
\hline Transversal line scales & $4 / 7$ & & & $4 / 8$ & $3-5$ & $7-10$ \\
\hline Scales Pectoral-Pelvic & 5 & & & 4 & & 6 \\
\hline Cheek scales & 4 & & & 4 & & 5 \\
\hline
\end{tabular}

Table 5. Measurements and meristics for Astatoreochromis straeleni (Poll, 1944) and A. alluaudi Pellegrin, 1904. 
specimens contained some adult insect remains and other invertebrate material, but no snails. The guts of three other specimens contained a large amount of debris, sand and small undigested plant fragments. Finally, three mouthbrooding females had empty guts.

\section{Reproduction}

The species is a mouth-brooder but nothing has been reported about its breeding period. Among the specimens captured in the Malagarazi in December 2008 and in the Rusizi in January 2011, females were found with ovarian eggs at different developmental stages in their gonads. Those caught in January appeared to be at a more advanced stage and almost mature for spawning (diameter: 1.9-2.6 mm). Conversely, amongst the specimens caught in the Rusizi basin in February 2009, no females with developed eggs in their gonads were found. So, most probably the species reproduces at the start of the short dry season from December to January. Whether this is the only reproductive season cannot be determined from our data.

\section{Discussion}

Intra-specific geographic differentiation was observed in both A. alluaudi and A. straeleni, mainly in LPJ proportions. Within the former species, these differences were found in populations corresponding to the two former subspecies $A$. a. alluaudi and A. a. occidentalis, while within the latter, differences were found between the Malagarazi and Rusizi populations, previously identified respectively as A. vanderhorsti and A. straeleni. Removal of the LPJ measurements from PCAs, in both species led to a larger overlap between geographically isolated populations (Figs 2-3).

Several authors have discussed phenotypic plasticity of the LPJ in A. alluaudi (Greenwood 1965a; Hoogerhoud 1984, 1986; Huysseune 1995; Smits et al. 1996a; Witte et al. 1990, 1997) and its consequences on adjacent structures in the head (Barel et al. 1977; Smits et al. 1996b) and the discovery of environmental effects shaping pharyngeal structures was the reason why the subspecific division within A. alluaudi was abandoned (Greenwood 1965a). Our results indicate that this phenotypic plasticity, in natural conditions, is linked to differential growth trajectories of the pharyngeal jaw between the populations examined. Interestingly, in an analysis with two size classes we observed contrasting patterns of intraspecific differentiation in LPJ morphology for the two species examined. In A. alluaudi few differences were observed among small specimens $(<75 \mathrm{~mm} \mathrm{SL}$ ) while all four LPJ measurements (and some other measurements on the body as well) were highly significantly different in larger specimens. This finding accords with Hoogerhoud (1986) who found a diverging allometric relationship between two other LPJ measurements, i.e., horn width and keep depth, when comparing the Lake Victoria population with those from other lakes in the region. In contrast, LPJ growth trajectories appear to be different within geographically isolated populations of $A$. straeleni from the Lake Tanganyika basin. Here we found all LPJ measurements to be highly significant between the Rusizi and the Malagarasi population in specimens $<75 \mathrm{~mm}$ SL, while not significant in larger specimens. This might indicate that environmental effects on the pharyngeal structures do not necessarily follow the same ontogenetic pathway in closely related haplochromine species. However, a more detailed study of pharyngeal morphology is necessary to fully understand this phenomenon. The other measurements on head and body structures that were also significantly different in small specimens were also not significantly different between the Rusizi and the Malagarazi in larger specimens.

According to Greenwood (1954), A. vanderhorsti differed from A. straeleni by a slightly deeper lachrymal, LPJ shape, and an almost horizontal mouth. However, Greenwood's study was based on the only two specimens of $A$. straeleni known at the time. We could not confirm the difference in mouth inclination, and found no significant difference in lachrymal depth between the populations from the Rusizi (identified as A. straeleni) and from the Malagarazi (A. vanderhorsti) as the values showed almost 
complete overlap (11.1-15.8 vs. 12.1-16.6\% HL, respectively). However, when the test group was split into two different size classes, a significant difference was found in specimens $<75 \mathrm{~mm} \mathrm{SL}$, but was absent in specimens $>75 \mathrm{~mm} \mathrm{SL}$ (Table 4). Greenwood (1954) did not state whether the shape of the LPJ was visually evaluated or whether precise measurements were compared. In this study, the shape of the LPJ is expressed by four different measurements, all of which were significantly different (Table 3) between individuals of the Rusizi and the Malagarazi populations. When the test group was split into two size classes, these differences could still be observed in specimens $<75 \mathrm{~mm} \mathrm{SL}$ but, as for the other features, were not evident in specimens $>75 \mathrm{~mm}$ SL (Table 4).

Slight differences between $A$. straeleni and $A$. vanderhorsti in anal and dorsal spine counts were reported by Greenwood (1979), a finding confirmed in this study. It should be noted that one specimen from the Malagarazi was found with 19 dorsal spines and five specimens from the Rusizi with 16 dorsal spines, whereas the known range for the Malagarazi basin was reported to be 16-17 dorsal spines (Greenwood 1954) and 17-18 dorsal spines for the Rusizi basin (Poll 1974). Five specimens of the 57 examined from the Rusizi were found to have 4 anal spines. This did not result in any significant difference for all the comparisons performed.

De Vos et al. (2001a) did not mention A. vanderhorsti in their list of fish of the Malagarazi River basin, but instead mentioned $A$. straeleni, probably in anticipation of the synonymy of the two species finally demonstrated in this revision. The presence of this species together with some other Congolese elements in the Malagarazi system (e.g., Marcusenius stanleyanus (Boulenger, 1897); Labeo weeksii Boulenger, 1969; Raiamas salmolucius (Nichols \& Griscom, 1917); Polypterus ornatipinnis Boulenger, 1902; Polypterus endlicheri Heckel, 1847; Distichodus maculatus Boulenger, 1898; Citharinus gibbosus Boulenger, 1899; Micralestes stormsii Boulenger, 1902; Oreochromis upembae (Thys van den Audenaerde, 1964) and Alestes macrophthalmus Günther, 1867) are interpreted here as evidence supporting the pre-Tanganyika connection of the Malagarazi to the Congo River through the Lukuga.

\section{Acknowledgements}

We thank Melanie Stiassny and Barbara Brown (AMNH), James Maclaine (BMNH), Georges Lenglet (IRSNB) and Patrice Pruvost (MNHN) for the loan of Astatoreochromis specimens under their care, and Miguel Parrent (collection manager) for cataloguing the specimens in the MRAC collections. Gaspard Ntakimazi (University of Burundi) is acknowledged for his scientific support and guidance of the first author. Gaspard Banyankimbona is supported by a PhD grant from the Belgian Technical Cooperation (BTC) at the University of Leuven (KU Leuven) and a research grant from the International Foundation for Science (IFS A4965-1/July 2010).

\section{References}

Barel C.D.N., Van Oijen M.J.P., Witte F. \& Witte-Mass E. 1977. An introduction to the taxonomy and morphology of the haplochromine Cichlidae from Lake Victoria. Netherlands Journal of Zoology 27: 333-389. http://dx.doi.org/10.1163/002829677X00199

Bookstein F., Chernoff B., Elder R., Humphries J., Smith G. \& Strauss R. 1985. Morphometrics in Evolutionary Biology. Special Publication 15, Academy of Natural Sciences, Philadelphia.

Boulenger G.A. 1907. Zoology of Egypt. Fishes of the Nile published for the Egyptian Government. 2 volumes. Hugh Rees, London.

De Vos L., Seegers L., Taverne L. \& Thys Van Den Audenaerde D.F.E. 2001a. L'ichthyofaune du bassin de la Malagarazi (système du lac Tanganyika): une synthèse de la connaissance actuelle. Musée Royal de l'Afrique Centrale, Sciences Zoologiques 285: 117-135. 
De Vos L., Snoeks J. \& Thys Van Den Audenaerde D.F.E. 2001b. An annotated checklist of the fishes of Rwanda (East Central Africa), with historical data on introductions of commercially important species. Journal of East African Natural History 90: 41-68. http://dx.doi.org/10.2982/00128317(2001)90[41:AACOTF]2.0.CO;2

Greenwood P.H. 1954. On two species of cichlid fishes from the Malagarazi River (Tanganyika), with notes on the pharyngeal apophysis in species of the Haplochromis group. Annals and Magazine of Natural History 7: 401-414.

Greenwood P.H. 1959. The monotypic genera of cichlid fishes in Lake Victoria, part II. Bulletin of the British Museum (Natural History), Zoology 5: 165-177.

Greenwood P.H. 1965a. Environmental effects on the pharyngeal mill of a cichlid fish Astatoreochromis alluaudi, and their taxonomic implications. Proceedings of the Linnaean Society of London 176: 1-10. http://dx.doi.org/10.1111/j.1095-8312.1965.tb00932.x

Greenwood P.H. 1965b. The Cichlid fishes of Lake Nabugabo, Uganda. Bulletin of the British Museum (Natural History), Zoology 9: 349-357.

Greenwood P.H. 1979. Towards a phyletic classification of the 'genus' Haplochromis (Pisces, Cichlidae) and related taxa. Part I. Bulletin of the British Museum (Natural History), Zoology 35: 265-322.

Hoogerhoud R.J.C. 1984. A taxonomic reconsideration of the haplochromine genera Gaurochromis Greenwood, 1980 and Labrochromis Regan, 1920 (Pisces, Cichlidae). Netherlands Journal of Zoology 34: 539-565. http://dx.doi.org/10.1163/002829684X00281

Hoogerhoud R.J.C. 1986. Ecological morphology of some cichlid fishes. PhD thesis. University of Leiden, The Netherlands.

Huysseune A. 1995. Phenotypic plasticity in the lower jaw dentition of Astatoreochromis alluaudi (Teleostei, Cichlidae). Archives of Oral Biology 40: 1005-1014.

Ntakimazi G. 1985. Hydrobiologie du Bugesera (Akagera - Haut-Nil), en particulier des lacs Cohoha Sud et Rweru en vue d'une gestion qualitative de la faune piscicole. Volume I-II. Dissertation, Fondation Universitaire Luxembourgeoise, Luxembourg.

Pellegrin J. 1904. Contribution à l'étude anatomique, biologique et taxonomique des poissons de la famille des Cichlidés. Mémoire de la Société Zoologique 16: 41-399.

Poll M. 1956. Poissons Cichlidae. Résultats scientifiques de l'exploration hydrobiologiques du lac Tanganyika (1946-1947), Institut Royal des Sciences Naturelles de Belgique, Brussels.

Poll M. 1974. Contribution à la faune ichthyologique du lac Tanganyika d'après les récoltes de Brichard. Revue de Zoologie Africaine 88: 99-110.

Rice W.R. 1989. Analyzing tables of statistical tests. Evolution 43: 223-225.

Slootweg R. 1989. Proposed introduction of Astatoreochromis alluaudi, an East African mollusk crushing cichlid, as a means of snail control. Annales en Sciences zoologiques 257: 61-64.

Smits J.D., Witte F. \& Povel G.D.E. 1996a. Differences between inter- and intraspecific architectonic adaptations to pharyngeal mollusk crushing in cichlid fishes. Biological Journal of the Linnean Society 59: 367-387. http://dx.doi.org/10.1111/j.1095-8312.1996.tb01472.x

Smits J.D., Witte F. \& Van Veen F.G. 1996b. Functional changes in the anatomy in the pharyngeal jaw apparatus of Astatoreochromis alluaudi (Pisces, Cichlidae) and their effects on adjacent structures. Biological Journal of the Linnean Society 59: 389-409. http://dx.doi.org/10.1111/j.1095-8312.1996. tb01473.x 
Snoeks J. 2001. Cichlid diversity, speciation and systematics: examples from the Great African Lakes. In: Coleman R.M. (ed.) Cichlid Research: State of the Art. Journal of Aquariculture and Aquatic science 9: $150-166$.

Snoeks J. 2004. The Cichlid diversity of Lake Malawi/Nyassa/Niassa: identification, distribution and taxonomy. Cichlid Press, El Paso, USA.

Stiassny M.J.L. \& Meyer A. 1999. Cichlids of the Rift Lakes. Scientific American 280: 64-69.

Vreven E.J., Musschoot T., Boden G. \& Stiassny M. 2007. Introduced or alien species of Lower Guinea. In: Stiassny M.L.J., Teugels G.G. \& Hopkins C.D. (eds) The Fresh and Brackish Water Fishes of Lower Guinea, West-Central Africa, Vol. 1: 57-101. IRD, MNHN, Paris; MRAC, Tervuren.

Welcomme R.L. 1988. International Introductions of Inland Aquatic Species. FAO Fisheries, Rome, Italy.

Witte F., Barel C.D.N. \& Hoogerhoud R.J.C. 1990. Phenotypic plasticity of anatomical structures and its ecological significance. Netherlands Journal of Zoology 40: 278-298. http://dx.doi. org/10.1163/156854289X00309

Witte F., Barel C.D.N. \& van Oijen M.J.P. 1997. Intraspecific variation of haplochromine cichlids from Lake Victoria and its taxonomic implications. South African Journal of Science 40: 585-594.

Manuscript received: 13 August 2012

Manuscript accepted: 7 January 2013

Published on: 22 February 2013

Topic editor: Rudy Jocqué

Desk Editor: Kristiaan Hoedemakers

Printed versions of all papers are also deposited in the libraries of the institutes that are members of the EJT consortium: Muséum National d'Histoire Naturelle, Paris, France; National Botanic Garden of Belgium, Meise, Belgium; Royal Museum for Central Africa, Tervuren, Belgium; Natural History Museum, London, United Kingdom; Royal Belgian Institute of Natural Sciences, Brussels, Belgium; Natural History Museum of Denmark, Copenhagen, Denmark. 